https://www.doi.org/10.33910/1992-6464-2021-201-63-76

Г. Ф. Горбунов, Е. А. Окладникова

РОССЙСКИЕ КУЛЬТУРНЫЕ КОДЫ «СПРАВЕДЛИВОСТЬ» И «БЛАГО/ БЛАГОПОЛУЧИЕ»: ТРАНСФОРМАЦИЯ ПОД ВОЗДЕЙСТВИЕМ ОБРАЗОВАТЕЛЬНЫХ, ЭКОНОМИЧЕСКИХ И ПОЛИТИЧЕСКИХ ФАКТОРОВ

\begin{abstract}
Цель статьи — описать современное состояние культурного канона России, в частности двух его базовых кодов «справедливость» и «благо/благополучие». Актуальность исследования определяется наблюдаемой педагогами, политологами, экономистами и соииологами деформаций смыслов этих кодов в сознании современных россиян. Работа осуществлена методом историко-культурного сравнительного анализа. Объектом исследования стал российский культурный канон, предметом исследования - влияние на деформачию культурных кодов "справедливость" и «благо/благополучие» трех определяющих культуру современной России факторов: образования, внутригосударственной политики и экономики.
\end{abstract}

Ключевые слова: культурный код, культурный канон, образование, внутригосударственная политика, экономика, Россия, «вызовы времени».

G. Gorbunov, E. Okladnikova

\title{
RUSSIAN CULTURAL CODES “JUSTICE" AND "WELL-BEING" AND THEIR TRANSFORMATION GUIDED BY EDUCATIONAL, ECONOMIC AND POLITICAL FACTORS
}

The article explores the state-of-the-art of Russia's cultural canon. In particular, it focuses on the two basic cultural codes, i. e., "justice" and "welfare/well-being". The meaning of the two codes is undergoing transformation which is highlighted by educators, political scientists, economists and sociologists alike. This makes the study relevant. The methodology included historical and cultural comparative analysis. The study focuses on the Russian cultural canon. In particular, it explores how the three factors shaping the culture of modern Russia - education, domestic policy and economy - influence the cultural codes "justice" and "welfare/well-being".

Keywords: cultural code, cultural canon, education, domestic policy, economy, Russia, modern day challenges.

\section{Введение}

Культурный канон как мыслительная конструкция транслирует системы культурных кодов народов из прошлого в будущее. Одним из первых, кто ввел в лексикон современной гуманитарной науки понятие «культурный код», был немецкий социолог и фрейдомарксист Эрих Фромм [23, с. 19]. Он использовал это понятие как метафору для обозначения совокупности общественных отношений, в основе которых лежит принцип массового потребления.
Культурный канон современного российского общества прошел три стадии исторического развития, выработав четыре последовательных сценария: Русь - самодержавная Россия/СССР - современная Россия. В былинном сценарии «Русь» главными действующими героями являются воин и купец, социальная структура общества это большая семья/рабочая артель, базовая ценность, маркирующая культурный код, справедливость. В эпоху становления русской государственности (Иван III) главный 
герой - священники и воин, базовой ценностью является благодать как маркер культурного кода. При Петре I главный герой воин/моряк/исследователь, базовая ценность - государство/народ/земля.

Признание существования самобытной российской цивилизации имеет важное значение в рассуждениях о российском культурном коде. Справедливость и благодать являются высшими нравственными ценностями, формирующими образ жизни русского/советского/современного российского человека. Религиозное, православное понимание справедливости и благодати (благополучия), лежащее в основе русского культурного канона, определяло тот фундамент, на котором покоилось доверие народа и правительства. Несправедливость понималась народом как несоответствие реального положения дел в сфере политики, экономики, образования и выражалась в разбалансировке отношений между различными социальными силами.

Справедливость . Справедливость - это универсальный моральный стереотип общечеловеческого сознания. В российском культурном каноне культурный код «сnраведливость" реализовывался как регулятивный принцип прежде всего в политической и экономической сферах жизни общества. Как социально-психологический феномен справедливость всегда проявлялась в пассивном внутреннем переживании населением страны происходящих экономических и политических процессов как «долюжное». Культурный код "сnраведливость» в российском обществе всегда реализовывался в форматах доверия личности к обществу, а главное, к государству. Основу форматов доверия определяла система моральных ценностей, близкая людям, которые выстраивали свои отношения с обществом и властью. Власть же, в свою очередь, организовала управление экономическими, политическими, культурными и образовательными сферами жизни общества.
Россия — аграрная страна вплоть до 1929 г., т. е. до провозглашения сталинского плана индустриализации страны. Исконно русская (т. е. от слова «Русь» как синоним государственности, о чем мы уже писали выше) идея справедливости как базовый культурный код российского культурного канона в советской модели общества (в 1917-1993 гг.) приобрела ярко выраженную экономическую коннотацию. Смыслы, которыми был исполнен культурный код «справедливость», были следующие: 1) культ труда; 2) формальное равенство рабочего класса и крестьянства (трудящихся, советского народа-созидателя).

Благодать/благополучие. На прагматическом уровне понятие «благо/благополучие» прежде всего ассоциируется с материальным достатком, обеспечивающим прогрессивное развитие общества. Культурный код «благо/ благодать/ благополучие» в истории России выходит на первый план в эпоху становления русской государственности, собирания земель под эгидой Московии (Иван III). Этот культурный код в российском обществе постепенно стал приобретать все больше экономических коннотаций и соотноситься с практиками распределения благ (прежде всего материальных) на основе систем ценностей, имманентных каждому из периодов истории страны. В каждый исторический период культурный код «благо/благополучие» имел свое философское обоснование.

Например, в советский период распределение благ осуществлялось на основе социалистических ценностей, принятых большинством населения страны. Базовый экономический принцип, на котором основан советский культурный код «благо/благополучие», транслируется всеми документами эпохи как формула: «От каждого - по способности, каждому - по труду».

Понятие «социализация» разрабатывалось макросоциологической теорией на основе фундаментального закона социальной эволюции. На основании разнообразных кейсов, описывающих процесс социализации, социологи выяснили, что культурный канон 
и составляющие его культурные коды транслируются человеку поэтапно: сначала семьей, затем школой, потом профессиональным образованием.

Сегодня смысловое пространство культурных кодов российского культурного канона трансформируется, девальвируется и постоянно сужается под ударами / «вызовами Истории». В практике социального бытия эти «вызовы» реализуются как образовательный (педагогический), внутригосударственный (политический и экономический) факторы.

Первый удар по российскому культурному канону нанесла Первая мировая война, но его спас доменный культурный код «сnрaведливости", по смыслу своему коллективистский, соборный, общинный, совместно-трудовой. Он основан на исконно русском понимании свободы творческого духа как «воли». Коннотацией смысла понятия «воля» являются необозримые просторы земли русской, породившие былинные образы богатырейзащитников, легендарных лихих атаманов вольных людей и образы реальных людей: путешественников-землепроходцев. Этот же принцип доменного культурного кода «сnрaведливость», понимаемого как «народный бунт», через цареубийство ограничил самодержавие. Пролетарская революция 1917 года предоставила российской нации возможность гордиться новым небывалым социальным проектом, а следующая война с Германией победоносно закончилась в Берлине. Во второй половине XX века Россия становится супердержавой и выходит в Космос.

Второй удар по русскому культурному коду был нанесен поражением в «лунной гонке». Российское руководство не нашло способ продолжить программу победоносного освоения космического пространства.

Третий удар был нанесен русскому культурному коду в 1990-е годы. Россия утратила статус сверхдержавы, попала под новое «англосаксонское» глобализационное иго. Но дело не в этом. Дело в том, что по мнению современной правящей элиты, российское общество должно утратить один из базовых смыслов своего культурного кода «справедливость» - его соборную, коллективистскую, общинную, трудовую доменную структуру. Российское общество, по мысли американских кураторов современной управляющей российской элиты, должно стать авторизированным, разобщенным, индивидуализированным. В 1990-е годы в российскую социально-экономическую повестку встала проблема выживания населения «любой ценой», которая на основе широко тиражируемого индивидуализма, нравственного эгоизма, интеллектуальной ограниченности, забвения традиций русской культуры, а также экспансии западной системы ценностей «культуры потребления» привела за последние 30 лет к безответственности власти и чиновников, распространению среди населения философии неолиберализма, дисбалансу изобилия и потребительскому буму при отсутствии реальных денежных средств и экономических возможностей у 90\% населения.

Четвертый удар российский культурный код пережил в 2020 году. Инфодемия и самоизоляция. В образовании — это «удаленка» (дистанционное образование). В экономике - слом малого и среднего бизнеса. Это сильный удар по волевому компоненту русского культурного кода «справедливость», укоренному в ощущениях бескрайних просторов, свободе передвижения, выбора образа жизни и деятельности.

\section{Постановка проблемы}

Цель настоящей статьи - описать процесс девальвации смыслов культурных кодов «справедливость» и «благо/благополучие» в культурном каноне современного российского общества. При описании причин девальвации смыслов этих двух базовых для русского культурного канона кодов возникают следующие вопросы: 1) Какие факторы оказали влияние на деформацию смыслов этих культурных кодов в области экономики? 2) Какие факторы оказали влияние на изме- 
нение смыслов культурного кода «справедливость» и "благополучие» в системе образования? 3) Какие смыслы вкладываются сегодня гражданами России в культурные коды «справедливость" и "благо/благополучие»? 4) С какими «вызовами Истории» столкнулся современный русский культурный канон?

В качестве гипотезы исследования мы выдвинули предположение о том, что такими факторами, в которых реализовался «вызов Истории» для русского культурного канона, в целом стали следующие: 1) внутригосударственный политико-правовой; 2) экономический; 3) образовательный.

\section{Сфера образования}

Сегодня в мире существует 200 государств. По уровню образования Россия занимает 52 место в мире, по уровню здравоохранения - 108 место и 112 место по состоянию дел в демографии. С одной стороны, уровень образования напрямую связан с культурным кодом «благо/благополучие», с другой с индексом «человеческого капитала». Высокий уровень образования работников затребован современным капиталистическим производством в условиях перехода от 5-го к 6-му экономическому укладу.

Ликвидация специалитета и введение бакалавриата, в соответствии с требованиями Болонского образовательного стандарта, резко понизила уровень подготовки кадров для всех сфер высокотехнологической производственной деятельности. Цель Болонской образовательной системы - сформировать личность «квалифицированного потребителя». Современный низкий уровень общей культуры и школьного образования у европейских и американских школьников - peзультат сознательной и целенаправленной работы политической элиты западных стран в пользу поддерживающих их глобальной финансовой и экономической элит [1, с. 60].

Задачи Болонской образовательной системы не имеют ничего общего с задачами общества недалекого будущего, а именно обществом «разумного потребления», и тем более с обществом 6-го и или 7-го экономических укладов. Современное российское общество крупных городов и мегаполисов с установками на «потребительскую гонку» цепко удерживает выпускников вузов, закрывая перед ними перспективу возвратиться на их малую родину, в российскую глубинку. Современная российская деревня больше не кормит себя и тем более страну, как это было раньше при колхозном строе. Фермерские хозяйства малочисленны и работают в основном на себя. Немногочисленные сельские жители подвержены потребительским и обывательским настроениям, в их среде распространяется правовой нигилизм, коррупция, индивидуалистические настроения и кадровый протекционизм.

По этим и другим причинам бюджетные затраты на образование и подготовку специалистов народного хозяйства не приносят ожидаемой отдачи, в регионах нарастает дефицит учителей, врачей, инженеров. Закрепление молодых учителей на работе сопровождается у них осознанием бесперспективности их личностного роста. Пример тому - «хрущевские деревни» 1960-х годов. Сегодня этот план признан непоправимой ошибкой. С завершением действия послевузовской системы распределения студенты московских и петербургских вузов не горят желанием возвращаться на свою родину. В условиях такой внутригосударственной миграционной политики в области образования в стране крайне трудно будет решить нарастающие социальные и экономические проблемы крупных городов России. Также в условиях роста бюджетных расходов сегодня руководство страны забыло о необходимости поднять на уровень 6-го экономического уклада демографические и экономические показатели Сибири и Дальнего Востока [16].

Информационное общество 6-го экономического уклада, на пороге которого сейчас стоят жители российских мегаполисов, это общество высокого социального риска. Тренды образовательного процесса в ближайшем будущем приобретут совершенно другие очертания. 
Культурный код «благо/благополучие» в системе советского образования включал идею о том, что средняя школа - это не только пространство, где ребенок получал знания. Это было место, где проходила его социализация: именно там он видел модель социальных взаимоотношений с принятыми в этом обществе правилами социального контроля (наказаниями за невыученные уроки и прогулы, поощрениями за успехи в получении знаний), социальных лифтов (золотые медали и победы на олимпиадах открывали путь к высшему образованию), социального фаворитизма, социальной девиации (школьные хулиганы). Социализация проходила под жестким учительским контролем. Реформаторы системы образования на глобальном уровне начали с введения Болонской системы и переписывания школьных учебников, профинансированного на средства Дж. Сороса.

С приходом цифровой эпохи в высоких кругах организаторов среднего и высшего образования, которыми неожиданно для многих непосвященных оказались вовсе не Министерство просвещения или Министерство науки и образования, а руководители финансовых корпораций (в России это Сбербанк), центр IT-технологий «Сколково» и ВШЭ, речь стала идти уже не о реформировании советской системы образования, а о смене образовательной парадигмы в целом [8]. В 2011 году «нанореформаторы» создали в недрах официальной власти глобалистскую структуру АСИ (Агентство стратегических инициатив). Именно в этом Агентстве один за другим стали появляться такие программные документы образовательных форсайтов, как «Образование-2030», «Карта образования - 2035», «Форсайт компетенций - 2030» [13]. Все эти программы стали результатами «форсайт-флота» (теплоходной поездки по Волге 500 бизнесменов, чиновников и других креативщиков). Именно эти люди генерировали идеи «общественной стратегии образования», в которой были зафиксированы: 1) отказ от учебников и учителей; 2) индивидуальные образовательные траектории; 3 ) замена экзаменов играми; 4) облачные сервисы вместо реальных знаний; 5) создание созданных под копирку интернет-курсов вместо живого общения ученика и преподавателя; 6) поголовная биометрическая идентификация учеников; 7) личные дела с рождения до смерти на каждого человека, включая отказ от наличных денег и полный контроль банков над счетами населения. Этот форсайт в области глобальной системы образования предполагает развитие искусственного интеллекта и, как следствие, интеграцию нейросетей с человеческим телом, равноправие роботов с человеческими «биообъектами» и др.

Новые реформаторы глобальной системы образования с гордостью называют себя трансгуманистами. Они пекутся совсем не о доступном для каждого деревенского школьника интернете, о планшетах и электронных досках. Они озабочены моделью управления системой начального, среднего и высшего образования. Согласно их коллективному замыслу: 1) современная система образования в России несостоятельна, ибо она не дает учащимся навыков. Знания (информация), которую дети и молодежь получают в школе, быстро выветриваются, так как не связаны с конкретными навыками, а именно: с навыками коммуникации, принятия решений, креативности и управления собой. При этом навыки системного мышления, процесс формирования научной картины мира, умение работать с важным и второстепенным, установки на созидательный кропотливый труд ими не упоминаются; 2) место организатора образовательного процесса на глобальном уровне по этому замыслу отведено «ИИ» (искусственный интеллект). Именно «ИИ» будет «будет драйвером всех остальных образовательных технологий, без исключения» [18]; 3) современная система образования в России должна быть полностью заменена программой «Образование-2030», которая была объявлена в 2018 году АСИ и членом его наблюдательного совета Г. О. Грефом. Программа была одо- 
брена МВФ, который настоятельно продвигает эту программу, работая с Государственной думой РФ [8]. По мысли реформаторов, задача ГД РФ - изменить под программу законодательную систему и создать соответствующие экономические и финансовые механизмы, чтобы программа «Образование-2030» заработала в полную силу. Куратор программы - Д. Н. Песков, IT-эксперт, который вместе со своими помощниками разработал дорожную карту проекта [12]. Согласно дорожной карте программы «Образование-2030»: 1) предполагается полный демонтаж классического школьного образования; 2) полное уничтожение всех направлений фундаментального образования (запрещение лекционно-семинарского типа обучения); 3) превращение вузов в бизнес-инкубаторы, работу в которых с обучающимися осуществляют ТНК-кураторы; 4) для детей управляющей элиты останется возможность престижного и дорогостоящего образования детей по модели «учитель - ученик», а для бедных - только дешевое цифровое дистанционное образование; 5) бедные будут учиться в «Метаверах» за счет крупных компаний, на которые затем в течение остальной жизни будут работать, отдавая выданные им кредиты на обучение (восполняя деньги компаний, вложившихся в их «человеческий капитал»). Дорожная карта «Образование-2030» обозначает следующие важные принципы, которые, по мысли авторов, определят ее судьбоносные контуры новой педагогики середины III тысячелетия: 1) геймификаиия, предполагающая, что процессом обучения молодого поколения будет управлять «ИИ»; 2) все образовательные технологии будут заменены играми. Игра должна стать новой нормой коммуникации, формирующей у обучающихся навыки командной работы, стремление к лидерству, совершенствующей конкурентные отношения; 3) смену педагогических форматов, ведущую к смерти «учителя-наставника-воспитателя», искоренение аттестатов об окончании школы, дипломов о завершении образования в вузе, уничтожение научных журналов и форматов цитирования, авторских прав. Отомрут учебники, а вместе с ними и общеобразовательная школа, исследовательский университет. Далее умрет книга, статья как признанная веками форма знаниевой коммуникации; 4) изменится образовательный ландшафт, в котором сначала будет вытеснена «траектория» развития. Затем будет упразднена система оценок - их заменит «паспорт компетенций». Появится «модель инвестиций» в человека нового трансгуманистического мира с системой финансовых и страховых инструментов, вписывающей человека в мир ТНК (транснациональных финансовых корпораций). Будет введена объективизация процесса обучения при помощи нейрофейсов, управляемая виртуальными тьюторами, образующими менторские сети [18]. Программа «Образование-2030» — это прогноз, план действий по организации глобального образовательного проекта, в котором места для России как суверенного государства со своим культурным каноном и своим культурным кодом «блага/благополучия" не предусмотрено.

Почему банкир Г. Греф, IT-эксперт Д. Н. Песков, МВФ, экономисты из ВЭШ создают проекты образования будущего для России, наносящие разительный удар по культурному коду "благо/благополучие» и всему российскому традиционному канону, а Министерства просвещения, Министерство науки и образования только визируют созданные банкирами, айтишниками и либеральными экономистами форсайтдокументы? Смыслы, которыми современный западный постмодернистский культурный канон наделяет культурные коды «справедливость» и «благо/благополучие», основаны на принципах меркантилизма, прагматизма и монетизации духовных ценностей. Неудивительно, что программный документ «Образование-2030», подготовленный ориентированными на западный постмодернистский культурный канон представителями фонда «Сколково» (П. О. Лукша, директор по 
реализации образовательных программ в департаменте корпоративного образования МШУ), АСИ (Д. Н. Песков, директор направления «Молодые профессионалы» в области продвижения проектов), ВШЭ, начали идеей о том, что образование - это источник получения денег для мировой финансовой элиты путем создания управляемого большинства людей, которые лишены возможности выбора. Это «оцифрованное» с детства большинство населения мира, включая Россию, будет обладать только одной компетенцией: пользоваться готовыми сервисами. Жизнь этих людей будет проходить под жестким контролем механизмов экономического принуждения. Авторам проекта «Образование-2030» удалось продвинуть свои идеи в Правительство РФ. Принятие этого документа к исполнению нанесет сокрушительный удар по традиционному культурному коду «благо/благополучие» и всему российскому культурному канону в целом.

Сфера внутригосударственной политики

К концу XIX века в России еще не успела сформироваться капиталистическая система отношений в ее классическом варианте, описанном в трудах К. Маркса и Ф. Энгельса. Отвечая на вопрос, что такое государство, философ Ф. Бастиа писал, что государство - это «великая мистическая иелостность, посредством которой одна группа людей стремится жить за счет другой» $[21$, p. 5,20$]$. Согласно гегелевской философии, государство - это социальный институт. Одна из основных функций его — распределение социальных, экономических, духовных благ, т. е. реализация в практике жизни культурного кода «благо/благополучие». В идеале это распределение осуществляется государством на основании понимания правящей элитой культурного кода «справедливость», либо на основе принципа «соборность, коллективизм» (социальное/социалистическое государство, народная демократия), либо на основании принципа «индивидуализм» (авторитарное/ капитали- стическое государство, либеральная демократия).

Октябрьская революция 1917 года в России дала движение воплощению в жизнь идеи социального/социалистического государства, провозгласив принцип «экономического равенства и справедливости». По сути дела, это было торжество русского (крестьянского) культурного кода «благо/благополучие» и его «соборного, коллективистского» принципа. Экономическое равенство и справедливость в понимании большевиков, взявших власть в октябре 1917 года, не предполагала начала работы по формированию гражданского общества и буржуазных свобод. Это было немыслимо для реалистически мыслящих большевиков в условиях недостаточности материального обеспечения основной массы рабоче-крестьянского населения страны. Для воплощения в жизнь провозглашенной В. И. Лениным на II съезде Советов рабочих и крестьянских депутатов идеи построения в России социального/социалистического государства необходимо было осуществить грандиозные задачи обобществления народной собственности и перевода экономики в планово-распределительный режим. Мерами по реализации этой идеи стали: 1) всеобщая трудовая повинность, а позднее - обязательный труд для всех; 2) в распределительных отношениях - мера труда и мера потребления; 3) кодификация социальных прав граждан, закрепленных в Конституции, хотя и без обеспечения многих гражданских свобод буржуазного общества и в условиях внерыночной экономики.

Социальное/социалистическое государство в Советской России складывалось не столько на базе развития материальной основы общества путем индустриализации и напряжения всех сил народа, сколько на духовно-нравственной основе: т. е. на реализации действия культурного кода «cnpaведливость" и его "соборного, коллективистского" принципа. Объявленное большевиками социалистическое государство Советской России приняло на себя обязан- 
ности проводника и гаранта социалистических преобразований. Эти преобразования должны были гарантировать скромный, но достаточный для выживания уровень жизни трудящимся (прожиточный минимум), право на труд, обеспечить всеобщее начальное образование, бесплатное образование и здравоохранение. В системе такого рода курируемых государством распределительных отношений главенствовал культурный код «справедливости». Именно он и получил название пролетарской социальной справедливости. Этот культурный код обеспечивал функционирование другого культурного кода «благо/благополучие» через подсчет количества и качества труда каждого члена советского общества [11, с. 224].

Социальное/социалистическое государство, как полагал И. В. Сталин, было создано в СССР в 1936 г., а в 1956 году Н. С. Хрущев провозгласил построение коммунистического общества в СССР. Свои представления об осуществлении проекта создания коммунистического общества в нашей стране Н. С. Хрущев аргументировал тем, что трудящиеся могут получать бесплатный хлеб в каждой столовой СССР. Это и есть коммунизм, полагал он. Сейчас это звучит смешно, но для выходца из крестьянской среды Н. С. Хрущева, пережившего несколько периодов голода, включая голод 1932 года, бесплатный хлеб в общественных столовых был символом победы коммунистической идеи в одной отдельно взятой стране.

К началу 1990-х годов культурный код «благо/благополучие» и сопряженный с ним моральный культурный код «сnраведливость», основанные на принципе «От каждого - по способности, каждому — по труду», исчерпали себя в силу следующих причин: 1) утопичности своего основания; 2) нарушения закона дифференциации и интеграции на уровне общих экономических законов; 3) отсутствия механизмов контроля и учета на индивидуальном уровне; 4) различия между принципами организации экономических и правовых отношений в капиталистических (западных) обществах и советском (социалистическом) обществе. Для сравнения, в российском обществе начиная с 1990-х годов декларируется строительство социального государства и укрепление основ гражданского общества. В русле смены политического курса произошла подмена понятий: социальное государство стало пониматься как государство культуры консюмеризма, в котором стала господствовать идеология вещизма и иждивенчества. В итоге социологические исследования показали изменение классовой структуры общества (10\% - богатые, $20 \%$ - нищие, $70 \%$ - бедные) [20, с. 45]. В настоящее «постковидное» время правящей элитой осуществляется экономическое уничтожение среднего класса. На условном Западе население живет в гражданском обществе, начиная с эпохи Просвещения. Экономика этого общества процветает за счет прибавочного продукта, а в социальной структуре этого общества средний класс составляет 70\%.

Факторами, которые способствовали деформации смыслов культурных кодов «сnpaведливость» и «благо/благополучие» в нашей стране во второй половине 1900-х годов, были следующие: 1) падение «железного занавеса»; 2) знакомство советских туристов с рекламными продуктами западного общества; 3 ) отработка западными спецслужбами на странах соцлагеря технологий «цветных революций» в соответствии с планом Маршалла: политические события 1950-х годов в Венгрии, 1960-х годов в Чехословакии, 1980-х годов в Польше, 1990 -х годов в России; 4) становление в России асоциального/ либерально-демократического государственного устройства со свойственными ему установками на криминально-девиантное поведение элитарных кругов, подрывающее экономические устои общественных отношений.

Отход в 1990-х годах от исчерпавшего себя принципа «От каждого - по способности, каждому - по труду», т. е. трансформация смыслов культурных кодов «справедли- 
вость» и "благо/благополучие», имманентных традиционному русскому культурному канону, ознаменовалось переходом к рыночным отношениям. Этот переход сопровождался ваучеризацией, имитацией законообразного передела общенародной собственности посредством залоговых аукционов. Эти аукционы устраивались в интересах узкой группы лиц. В итоге все эти меры не способствовали возникновению в России обещанного руководителями страны правового демократического государства. Политические реформы начала 1990-х годов привели к следующим результатам: 1) был разрушен советский уровень социальной защищенности граждан; 2) общие стратегии управления народным хозяйством прекратили свое существование; 3) государственный бюджет резко уменьшился и т. д. На фоне такого социально-демографического ландшафта стал явным тот факт, что внедрить западную либерально-демократическую модель в социальную политику государства тоже не удалось. Тем не менее проведенная политическими реформаторами «работа» с традиционными для русского культурного канона культурными кодами «сnраведливость» и «благо/благополучие» с целью изменения их смыслов получила следующие последствия: 1) было стимулировано в широких слоях населения ожидание «экономического чуда»: в короткие сроки без особого труда можно достичь уровня жизни стран Евросоюза и США; 2) маркетинговые проекты и поддерживающая их реклама отрабатывала в обществе установки на понимание «блага/благополучия» как индивидуального гедонизма; 3) в сознание граждан средствами политической рекламы были внедрены ложные идеи о невмешательстве государства в экономику и саморегулирование рынка; 4) в научной среде распространились установки на игнорирование трудовой теории стоимости в экономике; 5) повсеместное распространение в юриспруденции получила практика допущения нетрудовых доходов; 6) в правовой сфере стала нормой практика узаконивания необоснованного перераспределения прибавочной стоимости и легализации возможности на этой основе роста потребления материальных благ.

Культурный код «справедливость» в контексте рассуждений об особенностях внутригосударственной политики нагружен совершенно разными морально-этическими смыслами на Западе и в современной России. Европейский культурный код «справедливость» в упомянутом контексте имеет смысл «качество жнизни». Качество жизни измеряется такими экономическими показателями, как продолжительность жизни населения, уровень его грамотности, доход на душу населения, уровень занятости, характер инвестиций и инноваций, уровень вложений в развитие человеческого капитала. В современной России культурный код «справедливость" имеет единственный базовый смысл: «совесть". Морально-этическими установками христианских десяти заповедей принудить государственную власть осуществлять справедливую политику в отношении народа не удавалось еще никому в истории человечества. Тем не менее экономистами марксистского толка высказывалось мнение, что установить такой порядок товарообмена, при котором быть бессовестными в отношении управляемого народа властителям станет невыгодно, возможно. С этой целью в СССР внедрялся опыт воспитания коммунистической морали, начиная с дошкольного воспитания. Этот социальный эксперимент не выдержал испытания «вызовом Истории», в облике которого явил себя миру базовый социальный закон неравномерности развития (экономического, политического, социального) разных народов и наций.

\section{Сфера экономики}

Трансформация смыслов культурных кодов «справедливость» и «благо/благополучие» под влиянием смены политического курса российским руководством в 1990 -х годах оказала негативное влияние на экономическую сферу жизни российского общества. 
Культурный код «благо/благополучие» оказался резко деформированным в результате подмены принципа коллективного/индивидуального труда, труда на благо/благополучие коллективного актора, т. е. всего народа страны, и понимания людьми «созидания/созидательного труда» как основы благополучия, принципами, высвечивающими ценности культуры потребления западного общества. Цель этой экономической аферы заключается в распределении необоснованно высоких торговых прибылей в пользу мирового олигархического капитала. Глобальные финансисты достигают эту цель путем деформации традиционного русского культурного кода «благо/благополучие» и манипуляции с подменой его исходных смыслов коллективизм, община, соборность, коллективный труд ценностями общества потребления.

Э. Фромм полагал, что современное западное общество потребления возникло в результате развития капитализма. Отличительными чертами общества потребления, согласно его теории и теориям его единомышленников, являются: 1) бурное техническое развитие; 2) рост доходов определенных слоев населения, существенно изменяющий структуру потребления представителей этих социальных слоев [23, p. 168-169]; 3) снижение продолжительности рабочего дня и рост свободного времени; 4) размывание классовой структуры; 5) индивидуализация образовательных процессов; 6) формирование всеобщей потребительской зависимости как условие индивидуальной свободы [2, с. 92, 96-97]; 7) подмена культурного кода «свободы воли» культурным кодом «потребительской гонки» [24, pp. 29, 32, 34].

В идеале, как полагают ученые - апологеты культуры консюмеризма и современного западного общества как общества потребления, смысл культурного кода «благо/благополучие» как "потребительской гонки» ведет население западных стран к прогрессу, стабильности, обеспечивает им высокие потребительские стандарты и тем самым снижает социальную напряженность, уменьшает социальные риски, сдерживает экстремистские настроения и укрепляет толерантные отношения на межгрупповом уровне [25].

Тем не менее на практике оказывается, что смысл культурного кода «благо/благополучие» как «потребительской гонки» способствует в условиях современной России формированию разрушительных процессов деградации личности в условиях массовизации культуры (засилья поп-культуры), отвлечению трудящихся от борьбы за свои права, утрате населением национальной идентификации, слому традиционного (позднесредневекового) западно-европейского культурного канона в целом, разрушению государственности. В современной России «потребительская гонка» как часть системы социальных отношений, установившихся в условиях «рыночной экономики», способствовала развитию не поддающегося управлению хаотического спада экономики. Закономерной в этих условиях стала ликвидация реального сектора экономики и превращение страны в сырьевой придаток других западных экономических систем. Потеря реального сектора экономики сказалась в процессе обнищания населения и его люмпенизации в силу утраты стабильных условий жизни и полезной трудовой деятельности [14]. Население после проведения в 1992-1995 годах «шоковой терапии» (введения свободных цен и тарифов) было поставлено на грань физического выживания и ускоренного вымирания (смертность на 20\% стала превышать рождаемость) [6, с. 5; 7].

Другой исследователь особенностей современного капиталистического общества Жан Бодрийяр определил культуру консюмеризма как технологию самообмана. Он полагал, что: 1) в современном капиталистическом обществе Запада невозможны проявления подлинно человеческих чувств; 2) выставляемое напоказ изобилие является следствием скрытого дефицита (теория 
дефицитной экономики, создание искусственного дефицита для поддержания необоснованно завышенных цен на товары и услуги; 3) потребление превращается в культ; 4) нечистоплотные манипуляции политиков, бизнесменов, финансистов, маркетологов с целью наживы в сфере потребления причина парадоксов современного западного общества [3; 4, с. 78].

Нивелирование значимости культурного кода «благо/благополучие» в системе культурного канона современного российского общества демонстрирует индекс человеческого потенциала (ИРПЧ). Неудивительно, что, судя по результатам социологических опросов в 2021 году, более $60 \%$ респондентов заявили об отрицательном отношении к реформам 1990-х годов в России [5; 10]. По разным социологическим оценкам, примерно 60-80\% россиян считают необходимым развивать модель смешанной многоукладной экономики с ведущей ролью государства на основе свободы и поддержки малого и среднего бизнеса в стране, создающего рабочие места и поднимающего трудовую активность $[20$, c. $89-90]$.

В западных странах, напротив, культурный код «благо/благополучие» увеличивал свою значимость в системе западноевропейского (протестантского по типу) культурного канона в силу следующих причин: 1) провозглашения принципа «государства всеобщего благоденствия»; 2) традиционно высокая экономическая активность населения; 3 ) установки правящей элиты на укрепление социального партнерства с помощью профсоюзов; 4) ускоренного процесса научнотехнического развития и перехода к 6-му экономическому укладу.

Сильный удар по культурному коду «благо/благополучие» традиционного русского и советского культурного канонов в эпоху неолиберальных реформ был нанесен: 1) отказом от плановой модели экономического развития с ее макрорегулятивными механизмами пропорционального производства и распределения; 2) отставанием в тем- пах модернизации в области высоких технологий (в России 0,9\%, тогда как в США достигает 40\%, в Германии и Японии более $30 \%$ ); только 3-5\% предприятий в России заняты инновационным производством; 3) разработкой стратегии замены сырьевой модели на инновационную и формирования мощной конкурентоспособной промышленности, которая позволит России осуществить переход к постиндустриальному, информационному обществу; 4) переходом к пострыночной экономике, характеристиками которой являются современные технологии (включая «искусственный интеллект», поставленный на службу управления обществом и государством; 5) изменением системы налогообложения не в пользу неимущих, а в пользу, напротив, богатых жителей страны [4, с. 57]. На поверку оказалось, что за счет бедных налогоплательщиков богатые (например, государственные чиновники высокого уровня) получают значительные по суммам пенсии; 6) массовому обнищанию людей, которые по закону достойны финансовой поддержки; 6) антинародной политикой банков и налоговых органов, вызвавшей закрытие малых предприятий и массовую недоплату налогов. Эта недоплата была обусловлена не злостным уклонением, а отсутствием хозяйственной деятельности и банкротством. В России в 2020 году прекратили свою деятельность 515,5 тыс. коммерческих организаций, или каждая шестая компания в стране. К таким результатам исследования пришла аналитическая служба международной аудиторско-консалтинговой сети FinExpertiza [14]. Это приведет к увеличению расходов федерального бюджета на пособия и уходу работников в теневую экономику, с сокращением служащих банков, налоговиков и судебных приставов; 7) неправильным социально-экономическим районированием хозяйственной деятельности. Сегодня Россия стоит перед выбором: 1) между цивилизованными рыночными отношениями или засильем всевластных экономических монополий, организующих эти 
отношения во вред не только государству, но и среднему и мелкому бизнесу; 2) между социально-ориентированной многоукладной экономикой и развитием, при котором увеличивается часть населения, живущая за чертой бедности; 3 ) между законами, обязательными для всех, и беззаконием, коррупцией, проникающей во все поры жизни общества; 4) между демократией и хаосом; 5) между повышением роли государства под реальным контролем общества и диктатурой [19, с. 34]. Путь, на который в 1990-х годах встала Россия, как сегодня оказывается, противоречив, динамика экономического развития не продумана, последствия не просчитаны.

\section{Выводы}

В современных условиях российский культурный канон и составляющие его культурные коды «справедливость" и «благо/ благополучие» трансформируются под влиянием экономических, политических и социальных факторов. Действие этих факторов обусловлено законами общественного развития, а именно: законом ускорения истории (на каждую последующую историческую фазу уходит меньше времени, чем на предыдущую) и законом неравномерности развития, или законом многолинейной эволюции (разные нации развиваются по-разному). Каждый из этих факторов предъявляет сегодня народу России свои «вызовы».

В 1990-х годах в России произошла революционная смена политического курса и основ государственного устройства. Россияне, чьи предки сражались в Гражданскую войну, победили в ВОВ, оказались, как и их деды и отцы в 1920-х годах, перед выбором: за кем пойти в будущее: за «белыми» или за «красными». В 1990-х годах наше общество встало перед дилеммой: какой проект будущего страны принять к реализации - «неолиберальный» (фронтмен Б. Н. Ельцин) или «коммунистический» (фронтмен Г. А. Зюганов).
Народ аграрной России в 1920-е годы определился, за кем идти в будущее, следующим образом. Русский крестьянин после Гражданской войны уже понимал, что «белый проект» был возвратом к кастовому феодальному обществу, в котором крестьянский сын не мог поступить в университет, воспользоваться социальным лифтом и стать руководителем страны, главным конструктором КБ или крупным ученым. «Красный проект» вел в бесклассовое общество, предоставлял крестьянскому сыну бесплатное всеобщее образование, бесплатную медицину, гарантировал занятость, обеспеченную пенсией старость. «Красный проект» будущего был имманентен смыслам традиционного русского культурного кода «справедливость» с его идеями формального равенства трудящихся - советского народа, с культом труда и «блага/благополучия», с его идеей соборности, коллективизма, созидательного труда. По сути, это был выбор между проектами «СССР 2.0» и либерально-демократическим проектом глобализации. Выбор был сделан в пользу глобализации и связанного с ним буржуазного неолиберального проекта будущего.

В условиях сделанного народом России в 1990-х годах судьбоносного выбора смыслы традиционно русских культурных кодов «справедливость" и «благо/благополучие» во всех сферах жизни российского общества под воздействием неолиберальных экономического, образовательного, внутригосударственного политического факторов были деформированы. То, что происходит сейчас с российским культурным каноном, можно рассматривать двояко: как попытку национального самоубийства или как очередной «вызов Истории». Оглядывая мысленным взором историю России, нетрудно заметить, что наш российский пассионарный народ «вызовы Истории» любит. Более того, наш народ научился давать на эти «вызовы» надлежащий ответ. 


\section{СПИСОК ЛИТЕРАТУРЫ}

1. Арнольд В. И. Новый обскурантизм и российское просвещение. М.: ФАЗИС, 2003. 60 с.

2. Бауман 3. Текучая современность / под ред. Ю. В. Асочакова. СПб.: Питер, 2008. 345 с.

3. Белянова А. М., Гудкова Т. В. Наследие Й. Шумпетера и проблемы экономического развития России // Вестник Московского университета. Серия 6. Экономика. 2013. № 2. С. 87-114.

4. Бодрийяр Ж. Общество потребления. Его мифы и структуры. М.: Республика; Культурная революция, 2006. $400 \mathrm{c}$.

5. Бутрин Д. Да не такой уж и малый // Коммерсантъ. № 143. 12.08.2020. [Электронный ресурс]. URL: https://www.kommersant.ru/doc/4450581 (дата обращения: 12.05.2021).

6. Волович В. Н. Введение // Рыночная экономика и социальная роль государства. СПб.: Северная звезда, 2014. С. 4-15.

7. Воронцов A. B. Рыночный капитализм как фактор депопуляции русского народа // Рыночная экономика и социальная роль государства. СПб.: Северная звезда, 2014. С. 45-68.

8. Глобалист-форсайтщик Дмитрий Песков // РИА Катюша. 16.07.2018. [Электронный ресурс]. URL: http://katyusha.org/view?id=10269 (дата обращения: 12.05.2021).

9. Глобальная реформа образования от Сбербанка и Германа Грефа // Яндекс Дзен. [Электронный pecypc]. URL: https://zen.yandex.ru/media/obucheniepro/globalnaia-reforma-obrazovaniia-ot-sberbanka-igermana-grefa-5fbddaf7d81aaf181b0e4512 (дата обращения: 12.05.2021).

10. Горбунов Г. Макроуправление и качество жизни народов России // Рыночная экономика и социальная роль государства. СПб.: Северная звезда, 2014. С. 201-218.

11. Гринберг Р. Свобода и справедливость. Российские соблазны ложного выбора. М.: Магистр; ИНФРА-М, 2012. $320 \mathrm{c}$.

12. Дорожная карта проекта «Образование-2030». [Электронный ресурс]. URL: https://asi.ru/upload docs/ Forsight/edu2030print 3364x1189.tiff (дата обращения: 12.05.2021).

13. Евзрезов Д. В., Майер Б. О. «Образование 2030» - вызов системе образования // Вестник Новосибирского государственного педагогического университета. 2014. № 2 (18). С. 118-132. https://doi.org/10.15293/2226-3365.1402.11

14. Жертвы перестройки - новый статус? // ВЦИОМ Новости. [Электронный ресурc]. URL: https:// wciom.ru/analytical-reviews/analiticheskii-obzor/zhertvy-perestrojki-novyj-status (дата обращения: 12.05.2021).

15. Образование для сложного общества. [Электронный ресурc]. URL: http://www.imc-eduekb.ru/ downloads/Peсурсные\%20центры/doklad p.lukshi.pdf (дата обращения: 12.05.2021).

16. Китайцы в Сибири и на Дальнем Востоке // Википедия. [Электронный ресурс]. URL: https://ru.wikipedia.org/wiki/Китайцы_ в Сибири и на_Дальнем Востоке (дата обращения: 12.05.2021).

17. Образование 2030: упразднение школ, учителей, учебников и оценок // Народный собор. [Электронный ресурc]. URL: https://narodsobor.ru/2020/07/08/obrazovanie-2030-uprazdnenie-shkol-uchitelejuchebnikov-i-oczenok (дата обращения: 12.05.2021).

18. Опубликован проект документа «Ключевые направления развития российского образования для достижения Целей и задач устойчивого развития в системе образования» до 2035 г. // Устойчивое развитие в сфере образования-2035. [Электронный ресурс]. URL: http://edu2035.firo-nir.ru/index.php/statiopublikovannye-uchastnikami-soobshchestva/86-klyuchevye-napravleniya-2035 (дата обращения: 12.05.2021).

19. Примаков E. Встречи на перекрестках. М.: Центрполиграф, 2017. 607 с.

20. Рыжков Н. Н. Тернистый путь России. М.: Вече, 2018. 401 с.

21. Bastiat F. The law. New York: Irvington-on-Hudson Publ., 1995. 233 p.

22. Baudrillard J. La Société de consommation. Ses mythes, ses structures. Paris: S.G.P.P. Publ., 1970. $317 \mathrm{p}$.

23. Fromm E. Flykten från freedom. Philosophical arkiv. Nyköping: Abraham Ilyich Fe, 2016. 289 p.

24. Lasch C. The minimal self: Psychic survival in troubled times. New York: W. W. Norton \& Company Publ., 1984. $402 \mathrm{p}$.

25. SeabrookJ. The race for riches: The human costs of wealth. Basingstoke: Marshall Pickermg Publ., 1988. $344 \mathrm{p}$.

\section{REFERENCES}

1. Arnol'd V. I. Novyj obskurantizm i rossiyskoe prosveshchenie. M.: FAZIS, 2003. $60 \mathrm{s.}$ 
2. Bauman Z. Tekuchaya sovremennost'/ pod red. Yu. V. Asochakova. SPb.: Piter, 2008. $345 \mathrm{s.}$

3. Belyanova A. M., Gudkova T. V. Nasledie Y. Shumpetera i problemy ekonomicheskogo razvitiya Rossii // Vestnik Moskovskogo universiteta. Seriya 6. Ekonomika. 2013. № 2. S. 87-114.

4. Bodriyyar Zh. Obshchestvo potrebleniya. Ego mify i struktury. M.: Respublika; Kul'turnaya revolyutsiya, 2006. $400 \mathrm{~s}$.

5. Butrin D. Da ne takoy uzh i malyj // Kommersant”. № 143. 12.08.2020. [Elektronnyj resurs]. URL: https://www.kommersant.ru/doc/4450581 (data obrashcheniya: 12.05.2021).

6. Volovich V.N. Vvedenie// Rynochnaya ekonomika i sotsial'naya rol'gosudarstva. SPb.: Severnaya zvezda, 2014. S. 4-15.

7. Vorontsov A. V. Rynochnyj kapitalizm kak faktor depopulyatsii russkogo naroda // Rynochnaya ekonomika i sotsial'naya rol' gosudarstva. SPb.: Severnaya zvezda, 2014. S. 45-68.

8. Globalist-forsaytshchik Dmitriy Peskov // RIA Katyusha. 16.07.2018. [Elektronnyj resurs]. URL: http://katyusha.org/view?id=10269 (data obrashcheniya: 12.05.2021).

9. Global'naya reforma obrazovaniya ot Sberbanka i Germana Grefa // Yandeks Dzen. [Elektronnyj resurs]. URL: https://zen.yandex.ru/media/obucheniepro/globalnaia-reforma-obrazovaniia-ot-sberbanka-i-germana-grefa5fbddaf7d81aaf181b0e4512 (data obrashcheniya: 12.05.2021).

10. Gorbunov G. Makroupravlenie i kachestvo zhizni narodov Rossii // Rynochnaya ekonomika i sotsial'naya rol' gosudarstva. SPb.: Severnaya zvezda, 2014. S. 201-218.

11. Grinberg R. Svoboda i spravedlivost'. Rossiyskie soblazny lozhnogo vybora. M.: Magistr; INFRA-M, 2012. $320 \mathrm{c}$.

12. Dorozhnaya karta proekta "Obrazovanie-2030". [Elektronnyj resurs]. URL: https://asi.ru/upload_docs/ Forsight/edu2030print 3364x1189.tiff (data obrashcheniya: 12.05.2021).

13. Evzrezov D. V., Mayer B. O. "Obrazovanie 2030" - vyzov sisteme obrazovaniya // Vestnik Novosibirskogo gosudarstvennogo pedagogicheskogo universiteta. 2014. № 2 (18). S. 118-132. https://doi.org/10.15293/2226$\underline{3365.1402 .11}$

14. Zhertvy perestroyki — novyj status? // VTsIOM Novosti. [Elektronnyj resurs]. URL: https://wciom.ru/ analytical-reviews/analiticheskii-obzor/zhertvy-perestrojki-novyj-status (data obrashcheniya: 12.05.2021).

15. Obrazovanie dlya slozhnogo obshchestva. [Elektronnyj resurs]. URL: http://www.imc-eduekb.ru/downloads/ Resursnye\%20tsentry/doklad p.lukshi.pdf (data obrashcheniya: 12.05.2021).

16. Kitaytsy v Sibiri i na Dal'nem Vostoke // Vikipediya. [Elektronnyj resurs]. URL: https://ru.wikipedia.org/ wiki/Kitaytsy v Sibiri i na Dal'nem Vostoke (data obrashcheniya: 12.05.2021).

17. Obrazovanie 2030: uprazdnenie shkol, uchiteley, uchebnikov i otsenok // Narodnyj sobor. [Elektronnyj resurs]. URL: https://narodsobor.ru/2020/07/08/obrazovanie-2030-uprazdnenie-shkol-uchitelej-uchebnikov-ioczenok (data obrashcheniya: 12.05.2021).

18. Opublikovan proekt dokumenta "Klyuchevye napravleniya razvitiya rossiyskogo obrazovaniya dlya dostizheniya Tseley i zadach ustoychivogo razvitiya v sisteme obrazovaniya" do $2035 \mathrm{~g}$. // Ustoychivoe razvitie v sfere obrazovaniya-2035. [Elektronnyj resurs]. URL: http://edu2035.firo-nir.ru/index.php/stati-opublikovannyeuchastnikami-soobshchestva/86-klyuchevye-napravleniya-2035 (data obrashcheniya: 12.05.2021).

19. Primakov E. Vstrechi na perekrestkah. M.: Tsentrpoligraf, 2017. $607 \mathrm{s.}$

20. Ryzhkov N. N. Ternistyj put' Rossii. M.: Veche, 2018. $401 \mathrm{c}$.

21. Bastiat F. The law. New York: Irvington-on-Hudson Publ., 1995. 233 p.

22. Baudrillard J. La Société de consommation. Ses mythes, ses structures. Paris: S.G.P.P. Publ., 1970. 317 p.

23. Fromm E. Flykten från freedom. Philosophical arkiv. Nyköping: Abraham Ilyich Fe, 2016. 289 p.

24. Lasch C. The minimal self: Psychic survival in troubled times. New York: W. W. Norton \& Company Publ., 1984. 402 p.

25. SeabrookJ. The race for riches: The human costs of wealth. Basingstoke: Marshall Pickermg Publ., 1988. $344 \mathrm{p}$. 